\title{
Archipel
}

ARCHIPEL Études interdisciplinaires sur le monde insulindien

$88 \mid 2014$

Varia

\section{Singapore and the Silk Road of the Sea, 1300-1800}

\section{Roderich Ptak}

\section{OpenEdition}

Journals

Édition électronique

URL : http://journals.openedition.org/archipel/530

DOI : 10.4000/archipel.530

ISSN : 2104-3655

\section{Éditeur}

Association Archipel

\section{Édition imprimée}

Date de publication : 10 octobre 2014

Pagination : 213-216

ISBN : 978-2-910513-71-9

ISSN : 0044-8613

\section{Référence électronique}

Roderich Ptak, "Singapore and the Silk Road of the Sea, 1300-1800 », Archipel [En ligne], 88 | 2014, mis en ligne le 11 janvier 2018, consulté le 25 septembre 2020. URL : http://journals.openedition.org/ archipel/530 ; DOI : https://doi.org/10.4000/archipel.530 


\section{Comptes Rendus}

John N. Miksic, Singapore and the Silk Road of the Sea, 1300-1800, Singapore: NUS Press and National Museum of Singapore, 2013. xii + 491 pages, illustrations. ISBN 978-9971-69574-3 (hb).

The title of this book is somewhat "open": Geographically, the so-called "Silk Road of the Sea" extends from Korea and Japan in the East to the shores of the Gulf, Red Sea and East Africa in the West, but in this case, there is no coverage of the entire sailing corridor and its many branches; the focus is on Singapore and its exterior links to China, continental and insular Southeast Asia and, occasionally, Sri Lanka and India. In other words, there is no full account of the "total system," the author only examines some of its segments from a local Singaporean perspective. One could write similar accounts by placing comparable ports and islands in a central position, with an aim of drawing a general picture of how they were connected to the maritime world in a specific period of time. Therefore, it might have been better to choose a different title for the present work, for example, "Singapore and its Place in Maritime Exchange (or Trade), 1300-1800." Furthermore, the author does not follow conventional models or theories; his narration reads like a vast synthesis of past academic research, mainly based on archaeological data and the interpretation of some well-known textual sources.

The book begins with Sir Thomas S. Raffles, effectively glorifying this man's interest in Singapore's past. Raffles' passion for cultural relics stood in sharp contrast to British colonial greed and the way British officials turned Singapore into a basis for further adventures. Not infrequently, certain historians are accused of producing accounts designed to built up an inflated identity. A critical mind may also say this of Miksic's book: Promoted by two leading institutions, it wishes to boost Singapore's poorly known past, the principal message being that this city's roots go back to very ancient times, and not to the arrival of the British. Moreover: "Archaeological discoveries prove that Singapore is not one of the youngest capitals of Southeast Asia, but is in fact one of the oldest. Kuala Lumpur, Bangkok, Naypyitaw, Phnom Penh, and Manila were all founded more recently.” (p. 436). This is a key message offered by Miksic, who also draws attention to the fact that "we have over 500.000 artifacts from ancient Singapore" (p. 22) - mostly fragments of different wares, one may add, collected during twenty-eight years of excavations.

Well, then, what is this book about? There is a curious time frame, which provides the starting point for Miksic's discussion. Historians are confronted with a complex archaeological heritage that, in essence, belongs to the period circa 1300-1400. There is not much before and not much after that. Just before 1400 "Singapore's golden age came to an abrupt end" (p. 20). From circa 1400 onwards, one still encounters a small settlement along the Singapore 
River; however, this site does not compare to the town found in the earlier period. So far, the period 1600-1800 seems to be an archaeological vacuum. Put differently, we are looking at one century with a rich archaeological record, but the remainder rests on a weak platform and the issue of continuity makes one feel slightly uncomfortable.

In spite of these unusual conditions the author was brave enough to draw a broad panorama that tries to link the island's uneven civilisational trajectory to a larger maritime context the "silk road" matrix - or rather to an interregional setting. The first sections of his book deal with the times, when Southeast Asia's continental and island polities, often influenced by Indian and / or Chinese elements, began to emerge more clearly. We then see the rise of Tang-China, the small empire of Min, and finally of the Song state, all of which had a strong impact on exchange along the "Silk Road of the Sea." The Yuan empire, usually depicted as a landbased entity, also played a decisive role in the maritime sector. In fact, starting from the eighth or ninth century onwards, China was the locomotive for the entire setting, as Philippe Beaujard has recently demonstrated in his gigantic work Les Mondes de l'Océan Indien (Paris 2012). This is where Singapore comes in (chapter 4) and where Miksic presents a large quantity of material evidence, divided into local products (mostly earthenware) and a variety of imports (chapters 5 to 7). Chapter 8 fills a special position: It deals with metals, coins, and glassware. The final sections reconsider Singapore's "partners," once again by combining archaeological and other data, and by taking readers beyond the magical time line of circa 1400 .

There can be no doubt that Miksic has assembled his archaeological mosaic with much diligence, and certainly with some success, while his use of the written sources raises questions. This has to do with the fact that many records are in Chinese. Evidently the author relied on extant translations and secondary works, mostly in English, without adequately considering the huge quantity of modern research in Chinese and Japanese. One source that he frequently cites is Rockhill's old translation of Wang Dayuan's famous Daoyi zhilüe. Rockhill's work may still be useful, but many historians now follow the identifications proposed by Su Jiqing. Ganmaili is one example (p. 170): this is not a place in Southeast Asia - it should refer to Hormuz. Xialaiwu is another case where Su provides additional explanations.

Besides these problems one encounters several unusual twists and turns in Miksic's study, which could have been avoided, if an experienced scholar in Chinese Studies had checked the manuscript prior to publication. This concerns several transcriptions; furthermore, reunification under the Sui did not take place in 581 (p. 63); one should distinguish between the Khitan and Jurchen (p. 99); the Song capital fell after 1260 (p. 128); cowries were used as currency (p. 140); the Penghu Islands are not between Taiwan and Luzon (p. 315); Zheng Chenggong did not "reconquer" (p. 318) Taiwan during the Ming dynasty; etc. Other cases are less obvious, for example the reference to "cranes' crests" (p. 182); this normally stands for the bony excrescence of the hornbills (various species), which are only mentioned later, on p. 285. Miksic also cites Zhou Qufei, whose work carries an amusing entry on betel-chewing in China (compare the misleading statement on p. 370); indeed, the Lingwai daida is not lost (p. 111), but available in several editions and a fine German translation by Almut Netolitzky; complementary information is contained in a Song text by Fan Chengda of which there is full English version by James M. Hargett; these modern works do not appear in Miksic's bibliography. Finally, there are many possible explanations for Shahuagong (p. 371); the famous Gudai Nanhai diming huishi, by Chen Jiarong et al. (Beijing 1986), and other sources might have been consulted for these "little things." 
But instead of commenting on such "decorative" elements and unnecessary misprints (for example, on p. 409: Melaka's conquest by the VOC in 1643), I should better address certain other points. Now and then Miksic compares old Singapore, or Temasik (Danmaxi), to selected ports in the Malay world and the greater ensemble of maritime Asia. He laudably sketches many similarities between these locations, but then tells us that the settlement which he is mostly interested in, was unique in several respects. For instance, he believes that old Singapore was not divided into "urban" compartments (kampong); foreigners were able to move from one quarter to the next and to mix freely (for example, p. 441). Probably this is to suggest that Singapore was more advanced than the rest (and even China, "where foreign merchants were confined to specific quarters and prohibited from contacting the local population"...). But whether the present "evidence," drawn from archaeology and various texts, is really enough to firmly support such an hypothesis, seems doubtful. One also wonders why the author accuses Claude Guillot of providing premature assertions (p. 83) in the context of Lobu Tua, while Miksic himself takes the liberty of constructing various images, which may at best be hypothetical. Another problem is related to the nature of the material record. The majority of all unearthed items point to close connections between the Singapore region and China, but Miksic does not seem to feel comfortable with that; he underlines that China provided durable products (ceramics, coins, etc.), while perishable goods may have been imported to Singapore from other regions in large quantities. The intention behind this assumption is clear: Early Singapore should come out as a truly international port and not just as a location heavily influenced by or even dependent on China. A further issue is this: If early Singapore really was so unique and important, why is there such an awkward hiatus in later periods? One may argue that important places rarely experience radical "gaps" in their "career"; in the case of Singapore, the long void which seems to follow a short golden age could suggest that this settlement may not have been as exquisite as one is inclined to believe; possibly it was just a small site predominantly used by Chinese merchants and sailors - a place that enjoyed some freedom and safety due to Chinese money and protection, to deliberately twist the image... (p. 442).

Recently Peter Borschberg has argued (in Journal of Asian History 46.2) that the name "Singapore" may imply something like "Gateway to the Coast / Kingdom / Port of China," and not necessarily "Lion's City"; perhaps one could add these alternative semantics to the Chinese stratum of Miksic's theme and the presentation on pp. 151-152. Furthermore, can we be sure that the physical shape of the area around Singapore really remained the same over the last few centuries? Geological / ecological changes in the Bintan-Batam-Karimun region may have impacted on the navigability of certain waterways, with implications for the growth and decline of small ports and villages. Lin Woling in his stimulating work Longyamen xin kao (Singapore 1999) undertook a thorough examination of the different sea channels; Miksic is aware of this study but he does not exploit the many options offered by it.

Chapter 10, on Singapore and Riau, is quite refreshing, especially because historians rarely consider Pulau Midai and the Natuna and Anambas groups in their accounts of maritime Southeast Asia. But again, the Chinese component could have been exposed more thoroughly; not infrequently ships sailing to the Middle Kingdom moved through these islands and navigational texts occasionally refer to them. Yes, one can perhaps agree with Miksic that all these locations, taken together, constituted something like "an extensive hinterland for fourteenth century Singapore" (p. 388), but if we imagine that Temasik had a population of some 10,000 souls (p. 405), if at all, in this period or later, then such a vision appears rather 
courageous. A small town, or perhaps just a prosperous village, does not necessarily need a vast "hinterland." Moreover, for later periods one may even turn the picture upside down: the small settlement on Singapore Island became an "adjunct" of some nearby area(s).

Historians often emphasize the importance of the Chola intervention (1025), although we practically know very little about the real course of this event. By contrast we know much more about the Yuan and their maritime activities. David Bade's Khubilai Khan and the Beautiful Princess of Tumapel (Ulaanbaatar 2002; republished Singapore 2013) gives a wonderful example of what one can extract from the sources. Moreover, Sinologists have divided the brief period of Yuan trade and politics in maritime Asia into different stages and perhaps one could try to relate these "sub-periods" to the fate of Temasik more systematically. Other ideas may be found in recent studies, for example Geoff Wade's "An Early Age of Commerce...," Journal of Southeast Asian Studies 40.2 (2009). In short, Miksic provides a long bibliography, but he leaves out some important titles: Hans Bielenstein's voluminous Diplomacy and Trade in the Chinese World, 589-1276 (Leiden 2005) for the tribute envoys, many Chinese works on early topics such as the missions by Zhu Ying and Kang Tai, Max Deeg's huge translation of Faxian's text, the Kedah monograph by Michel Jacq-Hergoualc'h, a long article by Johannes Kurz on Chinese texts dealing with Brunei / Borneo - to mention just a few examples. Miksic addresses all these topics, directly or at the side, therefore readers would have been grateful for recent "updates." Other possible additions concern the old works by Paul Pelliot, the monograph by Jacques Dars, some Portuguese studies dealing with the sixteenth century, and so on. One also wonders why his bibliography does not list the magnificently illustrated collection prepared by Aileen Lau and Laure Lau, Maritime Heritage of Singapore (Singapore 2005), which has much to offer for the period after circa 1500. This book is for general readers and scholars alike and follows similar intentions as Miksic himself, who wishes "to raise Singaporeans' awareness of the fact that the rise of their small island nation is not a recent historical accident...” (p. 23).

My comments partly stem from high expectations when reading Singapore and the Silk Road of the Sea. The archaeological sections are illuminating, indeed, and the way Miksic tries to align certain descriptive elements (found, for example, in the usual array of semi-historical Malay accounts) with the "underground" facts deserves admiration; but there are quite a number of other things, often technical in nature, that are not satisfactory. In conclusion, then, one has to state that Miksic's book reveals much zeal; it offers many archaeological details (perhaps too many for a general reader) and some interesting interpretations; it contains beautiful images, there is an index with important names, and there are useful maps as well; however, there is also a grey side, which makes it difficult to give a final assessment of this work.

Roderich Ptak

Loh Wei Leng, Badriyah Haji Salleh, Mahani Musa, Wong Yee Tuan \& Marcus Langdon (eds), Biographical Dictionary of Mercantile Personalities of Penang, George Town, Think City and MBRAS, 2013, 227 p. plates and maps. Foreword by Wang Gungwu. ISBN 978967-9948-659-2

This dictionary, which focuses on the mercantile male personalities who pioneered the 